\author{
Asian Journal of Economic Modelling \\ $\operatorname{ISSN}(e): \quad 2312-3656$ \\ $\operatorname{ISSN}(p): \quad 2313-2884$ \\ DOI: 10.184.88/journal.8.2021.92.105.121 \\ Vol. 9, No. 2, 105-121. \\ (C) 2021 AESS Publications. All Rights Reserved. \\ URL: www.aessweb.com
}

\title{
DETERMINANTS OF CHILD LABOUR IN CAMEROON: A BIVARIATE PROBIT MODEL ANALYSIS
}

\author{
Simeon Maxime \\ Bikoue
}

\author{
Advanced School of Economics and Commerce, University of Douala, \\ Cameroon. \\ Email:maximebikoue@yahoo.fr Tel:+237699921061
}

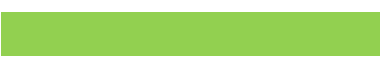

Article History

Received: 24 November 2020 Revised: 12 January 2021

Accepted: 2 February 2021

Published: 22 February 2021

\section{Keywords}

Determinants of labour

Children aged 5 to 17

ECAM data

Bivariate probit model

Child labour exploitation

Development policy.

\section{ABSTRACT}

The purpose of this article is to highlight the determinants of child labour for children aged 5 to 17 in Cameroon. The study uses microeconomic data from the third Cameroonian household survey (ECAMIII). The bivariate probit model reveals that the risks for a child who works are high if he does not go to school, he is fatherless or both parents are dead, the head of the family is not educated, he works in the agricultural sector, the standard of living of the household is low and he resides in rural areas. The study suggests that the issue of child exploitation in Cameroon is more global and necessarily falls within an economic and social development policy. From this perspective, the strategy to fight the particularly harmful exploitation of child labour should be cross-sectional because of the various dimensions of the phenomenon.

Contribution/ Originality: This study contributes to the existing literature by questioning the relationship between financial poverty and child labour from a bivariate probit model on investigation data in Cameroon. This study shows the multidimensional feature of explanatory factors at the helm of child labour.

\section{INTRODUCTION}

According to estimates by the International Labour Office (2002)1, there are over 190 million economically employed children aged 5-17 years in the world. These children are generally involved in agriculture, industry and services. In Africa, as in most developing countries, this phenomenon is also very preponderant. Nearly 50 million children aged 5-17 years are economically employed in sub-Saharan Africa, according to ILO estimates in 2006. This early employment of children is to the detriment of their education, For the case of Cameroon for example, we note that among young people (10-17 years), the highest activity rates are observed in regions where Gross Enrolment Ratios (GER) in primary education are the lowest. This is the case, for example, in the Far North region

\footnotetext{
${ }^{1}$ In the report resulting from the international labour conference held in Geneva in 2002, the International Labour Office (ILO) called for "a future without child labour" and for the effective abolition of this phenomenon to be achieved. "One of the most pressing imperatives of our time" (ILO, 2002). Early child labour could indeed compromise their physical and mental development and, at the national level, reduce the capacity to accumulate human capital (Anker, 2000; Ravallion \& Wodon, 2000). The fight to make it disappear therefore mobilizes international organizations (ILO, UNICEF, World Bank), non-governmental organizations as well as national public authorities (Dumas \& Lambert, 2008). Despite these repeated efforts, child labour persists. Recent estimates show that around 121 million children aged 5 to 14 (a rate of 9.9\%) are currently working worldwide (Diallo, Étienne, \& Mehran, 2013). The situation in Africa south of the Sahara is particularly worrying because, according to the same source, $21.7 \%$ of children of this age group work there.
} 
where the activity rate of young people aged 10-17 is around $75.9 \%$ and the GER is $92.0 \%$. against a national average of $101.1 \%$. The available statistics also reveal the existence of a probable link between the phenomenon of child labour and poverty, since the highest activity rates of children are observed in regions where poverty incidence rates are the highest.

This situation is believed to be due to the economic crisis of the 1990 s that Cameroon experienced and which was severely felt in some social sectors such as education. The volume of resources allocated to this sector has fallen sharply. The dysfunction of the system has contributed to a decrease in school attendance among young people (nearly $45 \%$ of these young people do not complete primary education). Moreover, a substantial proportion of those with higher education cannot find a job. In this context, education is no longer able to play for households this role of promoting well-being through employment which was once guaranteed on completion of the studies. Faced with such a situation, households, especially the poorest, adopt a survival strategy by looking for an alternative to the education of their children. One of these alternatives is to require the contributions of children in the economic life of the household through their increasingly extensive involvement in the labour market, mainly in segments that do not require a particular qualification.

As we will see later, the literature provides several arguments to explain child labour. Since the article by Basu and Van (1998) the most commonly cited factor is household poverty. It is in fact considered that households make the decision to have children work only if the family income excluding the children's contribution falls below the subsistence threshold ${ }^{2}$. However, the relationship between poverty and a number of empirical works ${ }^{3}$ : some advocate, on the contrary, that household wealth, when it is measured by their land possession, is one of the main causes of child labour (Bhalotra \& Heady, 2003). Following these authors, other factors of household vulnerability, such as parental unemployment, the death of the father and / or mother, or the decline in household income, have been put forward as possible explanations for the problem of child labour. Taking them into account sheds light on the policies to be adopted to reduce the phenomenon. The objective of this article is precisely to highlight the determinants of child labour using data from the third Cameroonian household survey (Ecam III), which was carried out in 2007 by the National Institute of Statistics (INS). We shall examine the influence of various household vulnerability factors, not just income poverty.

According to data from Ecam III, 28.8\% of children aged 5 to 17 work in Cameroon. The incidence is also much higher in rural areas than in urban areas (40.7\% versus 16.6\%). At the same time, the net primary school enrolment rate is estimated at $79.8 \%$ in 2007 ; still a long way from universal education, it has remained unchanged since 2001. Overall, the country's demographic structure is young: more than two in five Cameroonians (41\%) are under the age of 15 . Therefore, the dependency ratio ${ }^{4}$ stands at $80.1 \%$. In addition, in the second half of the 1980 s, the country experienced an economic crisis, the consequences of which are still perceptible ${ }^{5}$ on the standard of living of the populations. According to the INS (2008) poverty is thus high: out of a population of approximately 17.9 million inhabitants in $2007,39.9 \%$ live below the poverty line, i.e. roughly the same proportion as in 2001 (40.2\%), despite the significant debt reductions obtained during this period 6 ; rural populations are particularly affected, since they account for $87 \%$ of households in poverty in Cameroon.

\footnotetext{
2 These authors qualify this hypothesis as a "luxurious axiom" of poverty, cf. infra.

${ }^{3}$ See, for example, Canagarajah and Coulombe (1999); Nielsen (1998); Maitra and Ray (2002). Basu and Tzannatos (2003) quote some other research criticizing the poverty hypothesis.

${ }^{4}$ The dependency ratio represents the ratio of dependents - the population under the age of 15 or over 64 - and the working-age population - people aged 15 to 64 .

${ }_{5}^{5}$ The international financial crisis that occurred in 2007 and 2008 did not help the situation because it had the effect of a sudden drop in demand and therefore in the price of raw materials produced in Cameroon and for export, such as oil, wood, rubber, cotton and aluminium (Understanding Children's Work (UCW), 2012).

${ }^{6}$ In fact, during this period Cameroon left the "Heavily Indebted Poor Countries Initiative" program, which had the effect of relaxing the constraints linked to debt service.
} 
Non-monetary poverty indicators also point to a worrying situation. According to the report by Understanding Children's Work (UCW) (2012) "more than half of the population does not have access to improved sanitation facilities, more than a quarter do not have access to an improved water source and three fifths to electricity". In addition, the occurrence of events with negative consequences on income ${ }^{7}$ combined with poor labour, land or credit markets increases the opportunity cost of children's time, which is likely to increase their participation. at work and, at the same time, reduce the time they spend in school for education.

After summarizing the literature that deals with the determinants of child labour, we describe the econometric model adopted in the article, then specify the data and variables used in the analysis. We finally present the main results of the estimates made.

\section{LITERATURE REVIEW}

For the past 15 years or so, the issue of the determinants of child labour has been the subject of particular attention by development economists. But it is under the impetus of Basu and Van (1998) that the theory has developed in recent times. Their analysis focuses on the living conditions of households and the interaction between child labour and that of adults. It is based on a static model of household microeconomics whose main hypothesis, called the "luxury axiom", states that a household makes its children work if its income, without that of the children, falls below the threshold of household subsistence. Child labour is linked to poverty, which itself equates to insufficient parental income.

This axiom has been the subject of numerous empirical verifications which confirm the impact of poverty on child labour. Blunch and Verner (2000) using a simple probit model, demonstrate a positive and significant relationship between household poverty and child labour in Ghana.

Lachaud (2008) for his part uses a bivariate probit model and demonstrates that household monetary poverty, measured by consumption expenditures per capita, positively influences the work of children aged 5 to 14 in Burkina Faso. He also shows that there is a negative correlation between work and children's school education. Edmonds (2005) in his study based on panel data in Vietnam, suggests that a significant reduction in child labour is possible when the economic status of the household improves and points out that over the period 1993-1998, nearly $80 \%$ of the decrease in child labour stems from the improvement in economic conditions observed in the country.

However, in other studies, the correlation between poverty and child labour is weak, if not absent. Using Peruvian data, Ray (2000) concludes that there is no link because children can combine work and school, regardless of household status. It is the same for Jensen and Nielsen (1997) in Zambia, then Canagarajah and Coulombe (1999) in Ghana, who also do not find a significant relationship between child labour and household poverty. For these authors, poverty is not the first factor that accounts for the phenomenon child labour.

Although their analytical framework provides a better understanding of the conditions under which children are put into labour, the main criticism levelled at Basu and Van's model is that it does not take into account other factors - apart from household poverty - likely to influence the child labour market. More recent work has used household surveys from several developing countries to try to explain it better. These studies have taken various directions. Some have looked at access to credit and the imperfections of the labour market and land, while others have analysed the effect of negative shocks in the orientation of households.

Access to credit by households plays a key role in children's participation in work. Indeed, when the credit market works, it becomes possible for parents to borrow in order to finance children's education. However, in most developing countries these markets are imperfect. Under these conditions, the difficulty of access to credit encourages parents to make children work. In a study carried out in South Africa, Edmonds (2006) compares the status of children living with an adult eligible for a retirement pension to that of children living with adults who

\footnotetext{
${ }_{7}^{7}$ In 2007, there were more than 450,000 children (or 11\%) who had lost at least one parent (Understanding Children's Work (UCW), 2012).
} 
cannot. Receiving a retirement pension is a guaranteed income which can be used as a collateral for a loan. The author observes that children living with an eligible adult, on average, go to school more and work less. These results confirm that the possibility of borrowing against future income (here the retirement pension) allows households to invest in the education of their children. Other authors ${ }^{8}$ obtain similar results and find a significant relationship between child labour, school education and the imperfection of the credit market in various countries.

They point out that in the presence of credit constraints, child labour can become a recourse whenever parents are unable to make an inter-temporal arbitration over their resources. These various studies show that child labour is used by parents as a substitute for borrowing with the consequence of transferring income from the future to the present. It is thus not only a form of self-insurance, but also a safety net that poor households use to guard against imperfections in the credit market.

Another explanatory factor often considered in the literature concerns imperfections in the labour market and the land. Thus, faced with these imperfections, a household with large land in rural areas may prefer to employ their children rather than invest in their children's education. Using Pakistani and Ghanaian data to analyse the 'wealth paradox',9 Bhalotra and Heady (2003) find that land-rich households tend to employ their children as long as they cannot rely on an external labour force and that they have difficulty letting their land. As land is an important source of wealth in rural areas, these authors find that children from land-rich rural households are on average less educated and more active than those from landless households. Dumas (2007) in her study on Burkina Faso, shows that land ownership increases child labour when there are moral hazard problems concerning adult workers in the labour market ${ }^{10}$. It shows that, for all household categories, there is a U-shaped relationship between children's working time and the amount of cultivable land ${ }^{11}$.

Recent studies by Boutin (2012) and Dumas (2013) establish a positive relationship between child labour and some market imperfections, respectively in Mali and Madagascar. Boutin (2012) analyses the "wealth paradox" by testing the relationship between land ownership and child domestic labour. Using a logit model, she finds that the demand for child labour within the family increases with land ownership. In addition, the larger the cultivable area, the less likely children are to work outside the family farm. Dumas (2013) concludes that owning land is associated with a decrease in child labour when labour market imperfections diminish. One of the possible measures to fight against child labour would therefore be to promote competition in the labour market.

The shocks to which households are subjected are also factors of vulnerability that encourage children to work (Meka'a \& Ewondo, 2015). In fact, in the absence of insurance or reparation mechanisms (access to credit and insurance markets, social security system, etc.), households that are confronted with transitory income shocks or non-monetary shocks tend to withdraw their children from school in order to make them work and thus balance their consumption. Beegle, Dehejia, and Gatti (2006) seek to assess the extent to which transitory household income shocks lead to increased child labour, and whether access to credit decreases these effects. Using data from a sample of eight households in Tanzania, the authors manage to show that agricultural shocks ${ }^{12}$ lead to a substantial increase in child labour. Moreover, households with assets can use them not only to cope with shocks, but also as a guarantee of access to credit. De Janvry, Finan, Sadoulet, and Vakis (2006) using data from the Progresa ${ }^{13}$ experience in Mexico, point out that idiosyncratic shocks (unemployment or illness of the head of the family) or

\footnotetext{
${ }^{8}$ Such as for example: Jensen and Nielsen (1997); Baland and Robinson (2000); Dehejia and Gatti (2002); Guarcello, Mealli, and Rosati (2010).

9 The term is used to describe the situation of "wealthy" households employing their children.

${ }^{10}$ Some adult workers take the risk of reducing or degrading their labour supply, as they place themselves in the perspective of employing their children on family farms.

${ }^{11}$ In other words, child labour decreases when households own relatively small amounts of cultivable land, but increases as these amounts grow larger.

${ }^{12}$ For example, accidental crop losses or natural disasters (leading to lower income).

1s Progresa is a fund transfer programme that conditions children's school education and regular health monitoring.
} 
covariates (natural disasters) push parents to adopt risk management: they take their children out of school to put them to work. Using the propensity score matching (PSM) methodology on data from Guarcello et al. (2010) seek to know to what extent risk and vulnerability factors such as the rationing of credit and individual or collective shocks influence household decisions about education and thus child labour market. They conclude that the occurrence of these shocks reduces the level of education of children and increases their presence in the labour market.

Similarly, in a study from Tanzania, Bandara, Dehejia, and Lavie-Rouse (2015) analyse the impact of monetary (agricultural shocks) and non-monetary (parental death) shocks on child labour using a model in which households maximize their utility based on their consumption and children's education level. In particular, they seek to determine whether access to credit and household assets can cope with these shocks. This study shows that agricultural shocks have a significant impact on child labour and that access to credit works effectively as a solution.

\section{THE ECONOMETRIC MODEL}

We build a model ${ }^{14}$ that materializes the choice of putting a child to work and / or sending him to school. Thus, to describe the economic activity of the child taking into account his education, we must then specify two dependent variables: $\left(W_{i}^{*}, S_{i}^{*}\right)$ which are continuous latent variables assumed to come from a normal distribution.

As these variables are unobservable, we define two qualitative binary variables $\left(W_{i}, S_{i}\right) \quad(\mathrm{H}$ which are the manifestation of $\left(W_{i}^{*}, S_{i}^{*}\right)$. Formally, the decision to put a child to work is described by the following model:

$$
W_{i}^{8}=X_{1 i} \beta_{1}+\varepsilon_{1 i}
$$

$W_{i}^{8}$ is the net benefit expected by the family by sending a child to work and $X_{1 i}$ is a vector that defines the characteristics of the child, the family, the community that determine $W_{i}^{8}, \varepsilon_{1 i}$ is the reduced centred error term. However, $W_{i}^{8}$ is not observable, and what we observe is the following binary variable:

$$
W_{i}=\left\{\begin{array}{l}
1 \text { the child works }\left(w_{i}^{*}>0\right) \\
0 \text { the child does not }
\end{array}\right.
$$

Similarly, the decision to put a child in school is described by the following latent variable:

$$
S_{i}=X_{2 i} \beta_{2}+\varepsilon_{2 i}
$$

\footnotetext{
${ }_{14}$ To assess the determinants of child labour, the literature highlights several types of econometric models. The most common are: multinomial logistic, sequential (sequential multinomial logis or hierarchical multinomial logis) and bivariate probit models. Each of the models has advantages and disadvantages. In fact, the choice of the estimation method depends both on the data and on the objective of the analysis sought. Because of its relevance and the advantages it offers compared to other models, the approach adopted in the context of this document is estimation by the bivariate probit, Indeed, this model makes it possible to take into account the interdependence between the two choices at the same time that it allows to test the probability for a child to work and / or to go to school. The model has two dependent variables and enables to estimate the probability for a child to work and / or to go to school. These two variables are: participation in economic activity and school attendance.
} 
$S_{i}^{*}$ is the net benefit obtained by parents when they send their children to school, $X_{2 i}$, represents the characteristics of the child, the characteristics of the family through those of the head of household.

$\varepsilon_{2 i}$ represents the error terms which have zero mean and constant variance.

Unfortunately, $S_{i}^{*}$ is unobservable. What we can observe is the following binary variable:

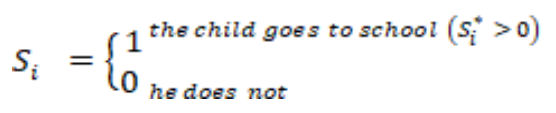

With $E\left(\varepsilon_{1 i}\right)=E\left(\varepsilon_{2 i}\right)=0$

The random terms, follow a bivariate normal distribution with the variances normalized to 1 as in the univariate probit, that is,

$V\left(\varepsilon_{1 i}\right)=V\left(\varepsilon_{2 i}\right)=1$ and $\operatorname{cov}\left(\varepsilon_{1 i}, \varepsilon_{2 i}\right)=\rho ; \rho \in[-1,+1]$

The normal cumulative function with two variables is written:

$\mathrm{P}\left(\Sigma_{1}<a, \Sigma_{2}<b\right)=\int_{-\infty}^{a} \cdot \int_{-\infty}^{b} \varphi_{2}\left(\varepsilon_{1}, \varepsilon_{2}, \rho\right) d \varepsilon_{1} d \varepsilon_{2}=\Phi_{2}(a, b, \rho)$

where $\varphi_{2}\left(\varepsilon_{1}, \varepsilon_{2}, \rho\right)$ is the density of the bivariate normal and $\Phi_{2}(a, b, \rho)$ is the distribution function of the same law.

with: $\varphi_{2}\left(\varepsilon_{1}, \varepsilon_{2}, \rho\right)=\frac{1}{2 \pi \sqrt{1-\rho^{2}}} e \frac{-\left(\varepsilon_{1}^{2}+\varepsilon_{2}^{2}-2 \rho \varepsilon_{1} \varepsilon_{2}\right)}{2\left(1-\rho^{2}\right)}$ which designates the correlation coefficient between the residuals of the two equations.

We have four possible observation regimes $\left(W_{i}, S_{i}\right) \in\{(1,1) ;(1,0) ;(0,1) ;(0,0)\}$.

The four possible combinations of $\left(W_{i}, S_{i}\right)$ and the probabilities associated with each observation are given by:

- children participate in the labour force and go to school, $W_{i}=1$ et $S_{i}=1$

$$
P\left(W_{i}=1, S_{i}=1\right)=P\left(W_{i}^{*}>0 ; S_{i}^{*}>0\right)=\Phi_{2}\left(X_{1}, \beta_{2}, X_{2}, \beta_{2,} \rho\right)
$$

- children participate in the workforce and do not go to school, $W_{i}=1$ et $S_{i}=0$

$$
P\left(W_{i}=1, S_{i}=0\right)=P\left(W_{i}^{*}>0 ; S_{i}^{*} \leq 0\right)=\Phi_{2}\left(X_{1}, \beta_{2},-X_{2}, \beta_{2}-\rho\right)
$$

- children do not work, but they go to school, $W_{i}=0$ et $S_{i}=1$

$$
P\left(W_{i}=0, S_{i}=1\right)=P\left(W_{i}^{*} \leq 0 ; S_{i}^{*}>0\right)=\Phi_{2}\left(-X_{1}, \beta_{2}, X_{2}, \beta_{2}-\rho\right)
$$


- $\quad$ children do not work nor go to school, $W_{i}=0$ et $S_{i}=0$

$$
P\left(W_{i}=0, S_{i}=0\right)=P\left(W_{i}^{*} \leq 0 ; S_{i}^{*} \leq 0\right)=\Phi_{2}\left(-X_{1}, \beta_{2},-X_{2}, \beta_{2}, \rho\right)
$$

In order to determine the parameters $\left(\beta_{1}, \beta_{2}, \rho\right)$ of the model, we maximize the likelihood function or the likelihood function defined respectively by:

$$
L\left(\beta_{1}, \beta_{2}, \rho\right)=\prod_{i=1}^{n} P\left(W_{i_{i}} S_{i}\right) \times 1 n L\left(\beta_{1,}, \beta_{2}, \rho\right)=\sum_{i=1}^{n} 1 n P\left(W_{i}, S_{i}\right)
$$

$X_{1 \mathrm{i}}$ and $X_{2 \mathrm{i}}$, are row vectors of explanatory variables which respectively determine the propensities to work and to go to school. $\beta_{1}$ and $\beta_{2}$ represent the column vectors of the parameters associated with the two equations. They are therefore solutions to the problem of maximizing the log likelihood of the model:

$$
\begin{gathered}
\left(\beta_{1}, \beta_{2}, \rho\right)=\operatorname{Argmax} 1 n L\left(\beta_{1}, \beta_{2}, \rho\right) \\
\beta_{1}, \beta_{2,} \rho
\end{gathered}
$$

The likelihood function of the bivariate probit presented in this model has a more complex shape and is difficult to estimate. However, some statistical software (Gauss, SAS, STATA ...) provide a maximization algorithm and the cumulative function of the bivariate normal distribution, it is relatively easy to determine the maximum likelihood estimator corresponding to the model. In addition, several marginal effects can be calculated. The bivariate probit estimates are obtained by maximum likelihood in full information. On a practical level, this involves estimating reduced equations of the determinants of work and access to education for children aged 5 to 17 . The econometric estimates under the STATA software are presented in Table 2.

\section{DATA}

Among children aged 5-17 years (around six million), 48.9\% do nothing but go to school and $28.7 \%$ study while working simultaneously (see Table 1). Likewise, 12.3\% do nothing but work and $10.1 \%$ neither attend school nor work. However, the proportion of children who work only increases with age.

Analysis by gender reveals a disparity between boys and girls. The percentage of girls who do nothing but work is higher than that of boys (14.3\% against 10.3\%). For those who do not attend school and do not work, the same trend is observed ( $11.9 \%$ against $8.3 \%)$. In addition, $31 \%$ of boys combine school and work against $26 \%$ of girls. According to the survey region, more than $70 \%$ of children in Yaoundé, Douala and the South have studies as their sole occupation. Depending on the area of residence, $75.4 \%$ of children in urban areas against $37.3 \%$ in rural areas do nothing but go to school.

\section{THE EXPLANATORY VARIABLES}

Based on previous studies (Adjiwanou, 2005; Boyden, 1992; Diallo, 2001; Diallo, 2008; Tsala, Dimbuene, \& Senda, 2005) available data and in the light of Cameroonian sociological realities, several factors likely to explain the child labour have been identified. These factors can be grouped into three broad categories: the characteristics of the child, the characteristics of the head of the family and the family environment. 
Table-1. Type of activity of children by sex, age group, survey region and place of residence.

\begin{tabular}{|c|c|c|c|c|c|c|c|c|c|}
\hline & \multirow{2}{*}{$\begin{array}{l}\text { Total } \\
\text { children }\end{array}$} & \multicolumn{2}{|c|}{$\begin{array}{l}\text { Do nothing but } \\
\text { work }\end{array}$} & \multicolumn{2}{|c|}{$\begin{array}{l}\text { Do nothing but go } \\
\text { to school }\end{array}$} & \multicolumn{2}{|c|}{$\begin{array}{l}\text { Work and go to } \\
\text { school }\end{array}$} & \multicolumn{2}{|c|}{$\begin{array}{l}\text { Neither go to } \\
\text { school nor work }\end{array}$} \\
\hline & & Number & $\%$ & Number & $\%$ & Number & $\%$ & Number & $\%$ \\
\hline \multicolumn{10}{|l|}{ Both sexes } \\
\hline $5-9$ & 2542891 & 155297 & 6.1 & 1485733 & 58.4 & 468128 & 18.4 & 433733 & 17.1 \\
\hline $10-14$ & 2196488 & 245003 & 11.2 & 992958 & 45.2 & 874442 & 39.8 & 84085 & 3.8 \\
\hline $15-17$ & 1213647 & 330312 & 27.2 & 433833 & 35.8 & 366691 & 30.2 & 82811 & 6.8 \\
\hline \multicolumn{10}{|l|}{ Boys } \\
\hline $5-9$ & 1254205 & 67727 & 5.4 & 756282 & 60.3 & 235045 & 18.7 & 195151 & 15.6 \\
\hline $10-14$ & 1144409 & 105154 & 9.2 & 530263 & 46.3 & 478880 & 41.9 & 30112 & 2.6 \\
\hline $15-17$ & 612448 & 138527 & 22.6 & 228501 & 37.3 & 220154 & 36.0 & 25266 & 4.1 \\
\hline Boys together & 3011062 & 311408 & 10.3 & 1515046 & 50.3 & 934079 & 31.0 & 250529 & 8.3 \\
\hline \multicolumn{10}{|l|}{ Girls } \\
\hline $5-9$ & 122686 & 87570 & 6.8 & 729451 & 56.6 & 233083 & 18.1 & 238585 & 18.5 \\
\hline $10-14$ & 1052079 & 139849 & 13.3 & 462695 & 44.0 & 395562 & 37.6 & 53973 & 5.1 \\
\hline $15-17$ & 601199 & 191785 & 31.9 & 205332 & 34.2 & 146537 & 24.4 & 57545 & 9.6 \\
\hline Girls together & 2941964 & 419204 & 14.3 & 1397478 & 47.5 & 775182 & 26.4 & 350100 & 11.9 \\
\hline \multicolumn{10}{|c|}{ Investigation region } \\
\hline Douala & 445308 & 19447 & 4.4 & 380069 & 85.4 & 25286 & 5.7 & 20506 & 4.6 \\
\hline Yaoundé & 469200 & 13892 & 3.0 & 402801 & 85.9 & 28635 & 6.1 & 23872 & 5.1 \\
\hline Adamawa & 329998 & 87775 & 26.6 & 9412 & 28.5 & 113603 & 34.4 & 34500 & 10.5 \\
\hline Centre & 435853 & 23172 & 5.3 & 256262 & 58.8 & 137315 & 31.5 & 19104 & 4.4 \\
\hline Est & 281453 & 57345 & 20.4 & 81825 & 29.1 & 116856 & 41.5 & 25427 & 9.0 \\
\hline Far North & 1172376 & 281927 & 24.1 & 322921 & 27.5 & 286967 & 24.5 & 280561 & 23.9 \\
\hline Littoral & 195735 & 12666 & 6.5 & 103659 & 53.0 & 73391 & 37.5 & 6019 & 3.1 \\
\hline North & 609175 & 110000 & 18.1 & 163248 & 26.8 & 215376 & 35.4 & 120551 & 19.8 \\
\hline North-West & 648507 & 51795 & 8.0 & 376505 & 58.1 & 186816 & 28.8 & 33391 & 5.2 \\
\hline West & 724968 & 37744 & 5.2 & 294388 & 40.6 & 376170 & 51.9 & 16666 & 2.3 \\
\hline South & 222637 & 9197 & 4.1 & 157483 & 70.7 & 48806 & 21.9 & 7151 & 3.2 \\
\hline South-West & 417816 & 25652 & 6.1 & 279243 & 66.8 & 100040 & 23.9 & 12881 & 3.1 \\
\hline \multicolumn{10}{|l|}{ Residence area } \\
\hline Urban & 1816738 & 91669 & 5.1 & 1369282 & 75.4 & 233004 & 12.8 & 122783 & 6.8 \\
\hline Rural & 4136288 & 638943 & 15.5 & 1543242 & 37.3 & 1476257 & 35.7 & 477846 & 11.6 \\
\hline Together & 5953026 & 730612 & 12.3 & 2912524 & 48.9 & 1709261 & 28.7 & 600629 & 10.1 \\
\hline
\end{tabular}

\subsection{Characteristics Specific to the Child}

They include the child's age, sex, kinship with the head of the family, whether or not they have attended kindergarten, school level, whether the child is fatherless or not. orphan of mother or not, orphan of both parents or not and the nationality of the child.

The age of the child: according to ILO Conventions No. 138 and No. 182, and the resolution concerning statistics on child labour, the age range retained for the measurement of child labour is "5-17 years". Age can influence children's propensity to work and stay in the workforce at the expense of school. Before 15 years of age, the child is still very immature and therefore psychologically fragile, very easily influenced by his parents and his family circle. Thus, the choices that are made for him or that he makes on his own concerning his school education or professional life are very often irreversible and can leave more pronounced stigmas than beyond the age of 15 . In addition, as school wastage increases with age, the risk of children's refuge in the professional world varies with their age (Chapter 6). It should be noted that the older the child, the more he is called upon to participate in the economic life of the household.

Gender: Previous studies of child labour show that there is gender discrimination in the decision to put children to work. Indeed, it appears that "girls work more than boys, and at all ages, and do not perform the same tasks" (Poirier, Baya, \& Zoungrana, 1996). In African and Cameroonian societies, in particular, the young girl is seen above all in her role of future wife and mother. This is why she is much more constrained to domestic, rural, 
and even commercial and other work than the young boy. In addition, in a context of declining income or the impoverishment of parents, the girl is very often disadvantaged in terms of school attendance in favour of work.

Family relationship: participation in work also varies depending on the child's family relationship with the head of the household. "The chief's children work less than other children” (Boyden, 1992). Likewise, depending on whether the child has a biological link with the head of the household or not, with the wife or not, whether he is adopted or entrusted, his risks of exercising a job at the expense of the school attendance decrease or increase.

Level of education: Raising a child's educational attainment can reduce the child's risk of working early given the workload required by school activities. These children will have little time to participate in subsistence activities (Marcoux, 1993).

The survival of the parents (child. Orphan of father and / or mother): the death of at least one of the parents makes the situation of the child very precarious. This situation is likely to jeopardize his school education or his hope of school survival, thus predisposing him to seize any employment opportunity in order to survive.

Nationality: compared to natives, the offspring of immigrants or foreigners, especially those who have themselves been working children, are more likely to find themselves early in the world of employment at the expense of school attendance.

Characteristics of the head of the family: The characteristics of the head of the family include gender, marital status, level of education, religion, the presence or absence of a disability in the head of the family, and socioeconomic group.

Gender of head of the family: Depending on whether the head of the family is male or female, the chances of a child going to school may increase or decrease.

Marital status: polygamous households are more conducive to child labour (Poirier et al., 1996) The same authors show that the instability of the union and especially its breakdown can influence the choices in terms of education or employment of children.

Level of education: In households where the head has a high level of education, the children who live there are more likely to go to school at the expense of work. In addition, increasing the level of education of the head of the family, particularly in rural areas, may be accompanied by the modernization of activities (for example, the modernization of agriculture that requires less labour) or their reorientation towards sectors requiring less child labour.

Religion: the perception of the place and role of the modern school in relation to that of the traditional school (informal and empirical learning) and the Koranic school depends, among other things, on religion. Indeed, depending on whether the head of the family is Christian, Muslim or animist, he or she may attach more or less importance to one or the other type of school.

Disability: the disabled situation of a head of the family can constitute a real obstacle to the education of his offspring, especially when the disability is combined with poverty.

Socio-economic status: The likelihood of a child being in the labour market decreases as the socio-economic status of the household improves (Tsala et al., 2005). Depending on the socio-economic group of the head of the family, the risk of working for their offspring at the expense of the school may vary. In addition, the fact that the father and especially the mother of the child is an employer can affect the choices regarding the education or employment of the children.

\subsection{Family Environment}

These are essentially the characteristics of the household grouping together the following variables the size of the household combined with the number of children aged $0-4$ and those aged 5-14, the standard of living of the household (very poor, poor, average, rich and very rich), the possession of some sustainable communicational goods 
in particular television, the radio, etc., the place of residence (urban, semi-urban and rural) and the area of investigation.

Household size: The cost of having a large number of children can influence the decision to make them all work or not. In addition, "the strategic models maintain that an individual's behaviour should be strongly influenced by the number of his brothers and sisters as well as the attitudes of the latter" (Diallo, 2001; Diallo, 2008). Thus, the fact that there are working children in the household increases the chances that others will also be workers, all other things being equal. The presence of children aged $0-4$ in the household can compromise the chances of attending school for children aged 5-17, especially girls called upon to play the role of babysitter.

Standard of living ${ }^{15}$ : the costs of education (direct costs in terms of tuition, books, uniforms, transport and snacks and indirect or opportunities related to the renunciation of child labour) can influence the decision of parents, especially the poorest to send their offspring to school or to the labour market. As poor households are more vulnerable, one of their survival strategies is to get their children to work in order to contribute to the household income.

Possession of some goods: the existence of television, in short communicational equipment in the household, by allowing household members to learn about current affairs, issues or challenges nowadays, can be a decisive factor of awareness raising in the fight against child labour (Adjiwanou, 2005).

Place of residence: the place of residence in which the household is located is a factor that can influence child labour. "In the city, most children devote themselves to studies. In the village, on the other hand, many children are at work" (Canagarajah. \& ET Coulombe, 1998; Nielsen, 1998). We are tempted to believe that the phenomenon is essentially rural. However, we generally observe that depending on the child's place of residence, his chances of going to school or the risk he runs of working may vary according to the level and the living conditions of this environment. Indeed, the absence or the remoteness of schools in certain rural areas can have a disadvantageous effect on the school attendance of the children residing there and therefore on their propensity to work.

From the above developments, several working hypotheses emerge, namely:

Child labour is the result of the trade-off between investing available resources in the human capital of their children and investing in physical capital.

The employment of children is negatively correlated with the standard of living of the household;

Children's activity is linked to their position in society; this socially constructed position that makes them social cadets. Thus, children in a household without at least one biological parent, illiterates, orphans, children of a certain age, children from certain backgrounds or regions, children living in a household where the head is not educated for example, are more exposed to work than others.

\section{RESULTS AND DISCUSSIONS}

The results obtained from the econometric estimates are summarized in Table 2. It can be seen that the coefficient indicating the correlation between the residuals of the two dependent variables of the model is statistically significant. This confirms the choice of the bivariate probit model. It should be remembered that the model we used seeks to explain the propensity to participate in the workforce and / or to go to school. The correlation coefficient is significantly negative in this estimate. This reflects the existence of a negative relationship between school attendance and child labour. The interpretation would be that unobserved factors that increase the likelihood of going to school decrease those of working.

\footnotetext{
${ }^{15}$ It should be noted that the standard of living of households was estimated by final consumption expenditure per capita. However, somes variables in the model, including human capital, possession of assets and work status, determine the standard of living of the household. This could be a source of endogeneity in the estimated model.
} 
Table-2. Results of the estimations of the bivariate probit model.

\begin{tabular}{|c|c|c|c|c|c|c|}
\hline \multirow{2}{*}{ Explanatory variables } & \multicolumn{2}{|c|}{ Child labour } & \multirow{2}{*}{$\begin{array}{l}\text { Marginal } \\
\text { effects } \\
\operatorname{Pr}(W=1)\end{array}$} & \multicolumn{2}{|c|}{ School attendance } & \multirow{2}{*}{$\begin{array}{l}\text { Marginal } \\
\text { effects } \\
\operatorname{Pr}(\mathbf{S}=1) \\
\end{array}$} \\
\hline & Coeff & $\mathbf{Z}$ & & Coeff & $\mathbf{Z}$ & \\
\hline $\begin{array}{l}\text { Characteristics Specific to the } \\
\text { Child } \\
\text { Gender }\end{array}$ & & & & & & \\
\hline $\begin{array}{l}\text { Girl } \\
\text { Boy } \\
\text { Family relationship with the head of } \\
\text { the family }\end{array}$ & $\begin{array}{l}\text { OO } 1946 \\
\text { Ref } \\
\text { Ref }\end{array}$ & 0.8 & 0.0065916 & $\begin{array}{c}-0.254424 \\
\text { Ref }\end{array}$ & $-6.63^{*}$ & $-0.0163073^{*}$ \\
\hline $\begin{array}{l}\text { Child of the head of household } \\
\text { Child entrusted } \\
\text { Child's age }\end{array}$ & $\begin{array}{c}\text { 0.037156 } \\
\text { Ref }\end{array}$ & 1.25 & 0.0125253 & $\begin{array}{c}0.251314 \\
\text { Ref }\end{array}$ & $5.85^{*}$ & $0.0176999^{*}$ \\
\hline $\begin{array}{l}\text { Age } \\
\text { Age squared divided by } 100 \\
\text { Nationality }\end{array}$ & $\begin{array}{c}0.310122 \\
-0.648262\end{array}$ & $\begin{array}{l}10.89^{*} \\
-5.26^{*}\end{array}$ & $\begin{array}{c}0.1050312^{*} \\
-0.2195511^{*}\end{array}$ & $\begin{array}{l}0.159239 \\
-1.99617\end{array}$ & $\begin{array}{l}2.68^{\prime *} \\
-9.06^{*}\end{array}$ & $\begin{array}{c}0.0100531^{*} \\
-0.1260129^{*}\end{array}$ \\
\hline $\begin{array}{l}\text { Cameroonian } \\
\text { Foreigner } \\
\text { Educational level }\end{array}$ & $\begin{array}{c}-0.214275 \\
\text { Ref }\end{array}$ & -1.48 & -0.076555 & $\begin{array}{c}0.563841 \\
\text { Ref }\end{array}$ & $2.85^{*}$ & $0.0597403^{*}$ \\
\hline $\begin{array}{l}\text { Primary } \\
\text { 1st cycle secondary } \\
\text { 2nd cycle Secondary and above } \\
\text { Without level } \\
\text { The child attended kindergarten }\end{array}$ & $\begin{array}{l}0.081957 \\
-0.248099 \\
-0.522239 \\
\text { Ref }\end{array}$ & $\begin{array}{l}1.53 \\
3.7^{*} \\
5.48^{*}\end{array}$ & $\begin{array}{c}0.0276148 \\
0.0808351^{*} \\
0.1487535^{*}\end{array}$ & $\begin{array}{l}0.586619 \\
1.944935 \\
3.107851 \\
\quad \text { Ref }\end{array}$ & $\begin{array}{l}5.54^{*} \\
15.85^{*} \\
15.32^{*}\end{array}$ & $\begin{array}{l}0.0430411^{*} \\
0.0758603^{*} \\
0.0345675^{*}\end{array}$ \\
\hline $\begin{array}{l}\text { Yes } \\
\text { No } \\
\text { The child is an orphan of mother or } \\
\text { father }\end{array}$ & $\begin{array}{c}-0.154237 \\
\text { Ref }\end{array}$ & $-4.9^{*}$ & $0.0516901 *$ & $\begin{array}{c}0.079047 \\
\text { Ref }\end{array}$ & 1.51 & 0.004911 \\
\hline $\begin{array}{l}\text { Motherless } \\
\text { Fatherless } \\
\text { Fatherless and motherless } \\
\text { Is not an orphan } \\
\text { The Family Environment }\end{array}$ & $\begin{array}{l}0.046035 \\
0.144541 \\
0.301952 \\
\quad \text { Ref }\end{array}$ & $\begin{array}{c}0.61 \\
2.87^{*} \\
2.77^{\prime}\end{array}$ & $\begin{array}{c}0.0157823 \\
0.0505376^{*} \\
0.1097243^{\prime}\end{array}$ & $\begin{array}{l}-0.019802 \\
-0.118507 \\
-0.280886 \\
\text { Ref }\end{array}$ & $\begin{array}{c}-0.17 \\
-1.73^{* * *} \\
-2.24 * * \\
\end{array}$ & $\begin{array}{c}-0.0012729 \\
-0.0230239 \\
-0.0230239 * * *\end{array}$ \\
\hline $\begin{array}{l}\text { Quality of life } \\
\text { Very poor }\left(Q_{1}\right) \\
\text { Poor }\left(Q^{2}\right) \\
\text { Medium }\left(Q_{3}\right) \\
\text { Rich }\left(Q^{4}\right) \\
\text { Very rich }\left(Q_{5}\right) \\
\text { Survey region }\end{array}$ & $\begin{array}{l}0.168792 \\
0.122315 \\
0.048057 \\
\text { O.041487 } \\
\quad \text { Ref }\end{array}$ & $\begin{array}{c}2.99^{*} \\
2.52^{* *} \\
1.06 \\
0.95\end{array}$ & $\begin{array}{c}0.0590097^{*} \\
0.0440303^{*} * \\
0.0163908 \\
0.0141405\end{array}$ & $\begin{array}{c}-0.123747 \\
-0.072798 \\
-0.072798 \\
-0.052121 \\
\text { Ref }\end{array}$ & $\begin{array}{c}-1.43 \\
-1.24 \\
-1.1 \\
-0.83\end{array}$ & $\begin{array}{c}-0.0085083 \\
-0.0061387 \\
-0.004769 \\
-0.0033822\end{array}$ \\
\hline $\begin{array}{l}\text { Douala } \\
\text { Adamawa } \\
\text { Centre } \\
\text { East } \\
\text { Far North } \\
\text { Littoral } \\
\text { North } \\
\text { North West } \\
\text { West } \\
\text { South } \\
\text { South West } \\
\text { Yaoundé } \\
\text { Place of residence }\end{array}$ & $\begin{array}{c}-0.013732 \\
0.556249 \\
0.373121 \\
0.947408 \\
0.441796 \\
0.703679 \\
0.580994 \\
0.154515 \\
0.943214 \\
0.143504 \\
-0.123298 \\
\text { Ref }\end{array}$ & $\begin{array}{c}-0.16 \\
6.84^{*} \\
4.75^{*} \\
12.06^{*} \\
5.86^{*} \\
8.96^{*} \\
7.33^{*} \\
2.13^{*} \\
13.51^{*} \\
1.75^{*} * * \\
-1.64\end{array}$ & $\begin{array}{c}-0.0046347 \\
0.2081386^{*} \\
0.1359863^{*} \\
0.3602273^{*} \\
0.1613397^{*} \\
0.2664819^{*} \\
0.2173733^{*} \\
0.0539261^{*} * \\
0.3533405^{*} \\
0.0502511^{*} * * \\
-0.0405009^{*} * *\end{array}$ & $\begin{array}{c}-0.031617 \\
0.156872 \\
0.137873 \\
0.070639 \\
0.126802 \\
0.287799 \\
0.327204 \\
0.085958 \\
0.290908 \\
-0.174981 \\
0.120888 \\
\text { Ref }\end{array}$ & $\begin{array}{c}-0.3 \\
1.37 \\
1.24 \\
0.66 \\
1.25 \\
2.32^{*} * \\
2.89^{*} \\
0.89 \\
2.94^{*} \\
-1.63 \\
1.17\end{array}$ & $\begin{array}{c}-0.0020492 \\
0.0086641 \\
0.0077828 \\
0.0042017 \\
0.0073017 \\
0.0142182^{*} \\
0.0158165^{*} \\
0.0051105 \\
0.015155^{*} \\
-0.0128008 \\
0.0069433\end{array}$ \\
\hline Semi-urban & 0.220482 & $5.84 *$ & $0.0778066^{*}$ & 0.192078 & $3.14 *$ & $0.0106272^{*}$ \\
\hline
\end{tabular}

Note: $*=$ significant at $1 \%$; $* *=$ significant at $5 \%$; $* * *$ significant at $10 \%$

\subsection{Explanatory Factors of Child Labour}

All things being equal, the propensity to work for children increases with age, decreases with education level and whether the child has attended nursery school or not.

Analysis of the characteristics of children indicates that their propensity to be part of the economically employed population increases with age. This can be explained by the fact that in the context of sub-Saharan Africa in general and Cameroon in particular, the work carried out by children is generally manual and physical tasks, which partly justifies that the older the child grows, the fitter he is to work. The negative value of the coefficient 
related to the squared age indicates that the probability of participating in economic activities increases sharply with age in the early years, then increases less and less, and then decreases.

\begin{tabular}{|c|c|c|c|c|c|c|}
\hline \multirow{2}{*}{$\begin{array}{l}\text { Dependent variables } \\
\text { Explanatory variables }\end{array}$} & \multicolumn{2}{|c|}{ Child labour } & \multirow{2}{*}{$\begin{array}{c}\begin{array}{c}\text { Marginal } \\
\text { effects }\end{array} \\
\operatorname{Pr}(\mathbf{W}=1) \\
\end{array}$} & \multicolumn{2}{|c|}{ School attendance } & \multirow{2}{*}{$\begin{array}{c}\begin{array}{c}\text { Marginal } \\
\text { effects }\end{array} \\
\operatorname{Pr}(\mathbf{S}=1)\end{array}$} \\
\hline & Coeff & $\mathbf{Z}$ & & Coeff & $\mathbf{Z}$ & \\
\hline $\begin{array}{l}\text { Rural } \\
\text { Urban }\end{array}$ & $\begin{array}{l}0.483054 \\
\text { Ref }\end{array}$ & $13.78^{*}$ & $0.1699741^{*}$ & $\begin{array}{l}0.211884 \\
\text { Ref }\end{array}$ & $3.92^{*}$ & $0.0124965^{*}$ \\
\hline \multicolumn{7}{|l|}{ Household size } \\
\hline $\begin{array}{l}\text { Size } \\
\text { Number of children aged } 0-4\end{array}$ & -0.025043 & -341 & $-0.0084814^{*}$ & 0.49463 & $-4.23^{*}$ & $0.0031227^{*}$ \\
\hline $\begin{array}{l}\text { Baby } \\
\text { Baby squared } \\
\text { Number of children aged 5-14 }\end{array}$ & $\begin{array}{l}-0.033292 \\
0.016035\end{array}$ & $\begin{array}{l}-1.56 \\
3.91^{*}\end{array}$ & $\begin{array}{l}-0.0112753 \\
0.0054306^{*}\end{array}$ & $\begin{array}{l}-0.083816 \\
-0.007231\end{array}$ & $\begin{array}{l}-2.94 * \\
-2.97^{*}\end{array}$ & $\begin{array}{l}-0.0052915^{*} \\
-0.0004565^{*}\end{array}$ \\
\hline $\begin{array}{l}\text { Child } \\
\text { Squared child } \\
\text { Presence of a television set }\end{array}$ & $\begin{array}{l}0.072922 \\
-0.006184\end{array}$ & $\begin{array}{l}3.7^{*} \\
-2.86^{*}\end{array}$ & $\begin{array}{l}0.0246968^{*} \\
0.0020945^{*}\end{array}$ & $\begin{array}{l}0049152 \\
-0.00645\end{array}$ & $\begin{array}{l}2.13 * * \\
-3.93^{*}\end{array}$ & $\begin{array}{l}0.0031031^{* *} \\
-0.0004072^{*}\end{array}$ \\
\hline $\begin{array}{l}\text { Yes } \\
\text { No } \\
\text { Characteristics of the Head of the } \\
\text { family } \\
\text { Age of head of the family }\end{array}$ & $\begin{array}{l}-0.0968 \\
\text { Ref }\end{array}$ & $-2.91^{*}$ & $-0.0327102^{*}$ & $\begin{array}{l}-0.017021 \\
\text { Ref }\end{array}$ & -0.32 & -0.0010758 \\
\hline $\begin{array}{c}\text { Age } \\
\text { Gender of the head of the family }\end{array}$ & 0.000624 & 0.52 & 0.0002134 & 0.003449 & $1.94 * * * *$ & 0.0002177 **** \\
\hline $\begin{array}{l}\text { Female } \\
\text { Male } \\
\text { Marital status of the head of the } \\
\text { household }\end{array}$ & $\begin{array}{l}0.045169 \\
\text { Ref }\end{array}$ & 1.17 & 0.0153829 & $\begin{array}{l}0.039604 \\
\text { Ref }\end{array}$ & 0.66 & 0.0024593 \\
\hline $\begin{array}{l}\text { Single } \\
\text { Polygamous } \\
\text { Widower / widow } \\
\text { Separated / Divorced } \\
\text { free Union } \\
\text { Monogamous } \\
\text { Head of family's education level }\end{array}$ & $\begin{array}{l}-0.048782 \\
0.045237 \\
-0.113849 \\
-0.091556 \\
-0.125762 \\
\quad \text { Ref }\end{array}$ & $\begin{array}{c}-0.83 \\
1.22 \\
-2.01 * * * \\
-1.28 \\
-1.74^{*} *\end{array}$ & $\begin{array}{c}-0.0163216 \\
0.0154496 \\
-0.0375846^{*} * \\
-0.0302305 \\
-0.0411142^{*} *\end{array}$ & $\begin{array}{l}-0.086399 \\
-0.107338 \\
-0.005051 \\
0.037519 \\
-0.072797 \\
\quad \text { Ref }\end{array}$ & $\begin{array}{c}-1.05 \\
-1.8^{* * * *} \\
-0.06 \\
0.32 \\
-0.67\end{array}$ & $\begin{array}{c}-0.005854 \\
0.0072583^{*} * * \\
-0.00032 \\
0.0022909 \\
-0.0049024\end{array}$ \\
\hline $\begin{array}{l}\text { Number of years of study } \\
\text { Religion of the head of the family }\end{array}$ & -0.011847 & $-2.86^{*}$ & $-0.0040122^{*}$ & 0.015979 & $2.36^{* *}$ & $0.0010088^{* *}$ \\
\hline $\begin{array}{l}\text { Christian } \\
\text { Muslim } \\
\text { Animist / other } \\
\text { Victim of a disability }\end{array}$ & $\begin{array}{l}-0.234097 \\
-0.571984 \\
\quad \operatorname{Ref}\end{array}$ & $\begin{array}{l}-4.76^{*} \\
-10.35^{*}\end{array}$ & $\begin{array}{c}0.0816057^{*} \\
-0.1716098^{*}\end{array}$ & $\begin{array}{c}0.022373 \\
-0.248932 \\
\text { Ref }\end{array}$ & $\begin{array}{c}0.27 \\
2.81 *\end{array}$ & $\begin{array}{c}0.0014271 \\
-0.0182435 * *\end{array}$ \\
\hline $\begin{array}{l}\text { Yes } \\
\text { No } \\
\text { Socio-Economic Group of the } \\
\text { head of the family }\end{array}$ & $\begin{array}{l}-0.060232 \\
\text { Ref }\end{array}$ & -1.19 & -0.0200813 & $\begin{array}{l}0.047645 \\
\text { Ref }\end{array}$ & 0.56 & 0.0028887 \\
\hline $\begin{array}{l}\text { Public sector } \\
\text { Formal private sector } \\
\text { Inactive } \\
\text { Farmer } \\
\text { Unemployed } \\
\text { Informal private sector }\end{array}$ & $\begin{array}{c}-0.23958 \\
-0.173808 \\
-0617358 \\
0.383642 \\
-0.550206 \\
\text { Ref }\end{array}$ & $\begin{array}{c}5.06^{*} \\
-3.14^{*} \\
-11.03^{*} \\
11.42^{*} \\
-4.25^{*}\end{array}$ & $\begin{array}{c}-0.076828^{*} \\
-0.0562285^{*} \\
-0.1833924^{*} \\
0.1327933^{*} \\
-0.1539089^{*}\end{array}$ & $\begin{array}{l}0.165668 \\
-0.038673 \\
0.253377 \\
-0.061988 \\
0.027521 \\
\quad \text { Ref }\end{array}$ & $\begin{array}{l}1.98^{*} * \\
-0.49 \\
2.92^{*} \\
-1.19 \\
0.2\end{array}$ & $\begin{array}{c}0.0093384^{* *} \\
-0.00252 \\
0.0129649^{*} \\
-0.0039735 \\
0.0016937\end{array}$ \\
\hline $\begin{array}{l}\text { Constant } \\
\text { Constant }\end{array}$ & -3.134446 & $-13.87^{*}$ & & 0.579041 & 1.57 & \\
\hline $\begin{array}{l}\text { Rho } \\
\text { Number of observations } \\
\text { Log likelihood } \\
\text { Prob }>C h i^{2}\end{array}$ & & & $\begin{array}{l}-03363324 * \\
15105 \\
-9603.3572 \\
0.0000000\end{array}$ & & & \\
\hline $\begin{array}{l}\text { Note: }{ }^{*}=\text { significant at } 1 \% ; * * * \\
\text { Ref }=\text { reference modality }\end{array}$ & ca & *** $=$ & icant at $10 \%$ & & & \\
\hline
\end{tabular}

Analysis according to the child's educational level reveals that, compared to children without an educational level, those with at least lower secondary education are less likely to find themselves in the labour market. It is the same for those who have attended nursery school. We can thus note that in Cameroon, early school attendance and raising the level of education seem to curb attempts to knock early on the doors of employment. 
Regarding the survival of parents, it influences the early entry of children into the labour market. Indeed, fatherless children and orphans of both parents have a greater propensity to work; whereas the fact that a child is motherless has no significant influence on its entry into labour. This result shows the preponderant role played by the father in the supervision of the child, especially in the financial support. We note that there is no discrimination based on sex, nationality and family relationship with the head of the family.

In terms of the family environment, as one might expect, child labour increases with declining standards of living. Both the poor and the very poor have a greater propensity to send their children to work compared to the very rich. However, the data does not show any discrimination in the phenomenon between children living in middle-income households and the rich and those living in households considered to be very rich. Accordingly, this result somewhat questions the traditional assumption that poverty is the main cause of child labour. The regions with the highest poverty rates (Far North, North, Adamawa and East) all fall into the category of regions with a high propensity for the mobilization of working children. However, there are regions with lower poverty rates such as the Centre, the Littoral, the North-West and the West. These results, in addition to household poverty, the socioeconomic and cultural environment of some regions may account for the motivations for putting children to work early. The analysis of the place of residence is also consistent with these results. Indeed, for a given standard of living and socioeconomic categories, the geographical location influences the activity of the offspring. Thus, children in rural areas and those in small towns are more likely to work than those in large towns, all other things being equal.

The composition of the household influences the participation of children in economic activities and highlights a certain constraint on their school education. In this sense, the larger the household, the less child labour will be required. In other words, the economy of scale factor would lead to the substitution of some household members for economic activities, thus providing the household with substantial means of subsistence. Thus, the entry of children into the labour market will occur much later. Furthermore, there is a ripple effect in households in that the preexistence of children aged 5-14 in the household favours the work of other children as well as their school education. These results are similar to those of Diallo (2008) in the case of Cotte d'Ivoire and Mali.

Possession of some communication goods including a television set is negatively associated with child labour. In other words, households with a television set are less likely to employ their children. These goods testify both to the standard of living of the household, but also to their capacity of households to be informed and to adapt to the new lifestyles which these means of communication are transmitting.

The head of the family is generally the main provider of funds for the household but also the decision-making hub. It is therefore logical that the characteristics of the latter can influence the behaviour of household members, including the economic activity of children. The level of education of the head of the family is found to be an important factor in understanding children's participation in the labour force. The results show that the higher the level of education of the head of the family, the more the offspring are spared from work. The hypothesis concerning the effect of the education of the head of the family on child labour is confirmed and broadly matches the results of Diallo (2001) and Grootaert (1998). Improving the level of education also leads to a reorientation of activities towards sectors employing less children, and facilitates access to financial markets, a possible source of financing for children's education; it thus improves their well-being.

The socioeconomic group (GSE) of the head of the family negatively influences the employment of children with the exception of farmers. While the propensity of children to be part of the economically employed population increases for children in households whose main source of income is agriculture, it decreases among those belonging to households headed by the public sector, the formal private sector or else is inactive or unemployed. Since the country's economy is largely based on non-mechanized agriculture, family labour is most often required. As noted in the other chapters, almost all (85.2\%) of the children carrying out work to be abolished are in agriculture / fishing / forestry / hunting sector. In addition, since households in this sector are the poorest, failing 
to acquire adequate and modernized tools for their agro-pastoral activities and other household work, they would make do with child labour which is generally available.

\subsection{Explanatory Factors for School Attendance}

The results on school attendance are consistent with previous studies. Indeed, all other things being equal, children's school attendance increases with age. However, this trend takes the form of an inverted U due to the negative sign of the variable age squared divided by 100. This could be explained by the not insignificant rates of "school wastage". Indeed, it emerges from the main report of ECAM3 that the repetition rate is $10.1 \%$ at the national level; $40 \%$ of children enrolled in primary education are lagging behind in school; nearly $23 \%$ of those over 5 have never attended school; Finally, there is a significant proportion of school dropouts.

Even if girls are less likely to go to school than the disappointed, it should be noted that the existence of a biological relationship with the head of the family increases the probability of schooling. Parents would therefore ensure that their own children are better educated than those in care. This result is reinforced by the fact that children who are fatherless or motherless are less likely to attend school than those whose two parents are still alive. To a lesser extent, fatherless children also have a very reduced chance of being in school.

The North, the Littoral and the West are the most favourable regions to the education of children. The West and the Littoral being mainly agricultural regions, children manage to reconcile school and work to be abolished. We also notice that in large cities - although it is less likely for children to exercise economic activity - the probability of being in school is lower than in small towns and rural areas. The rural environment, compared to the urban environment, would therefore have no detrimental effect on children's school education. Thus, the field work that children in rural areas perform do not distract them from their studies. This suggests a socialization of economic activity. In this environment, the child is born and grows up while seeing his parents do a number of jobs.

The probability of being in school increases with the size of the household. This suggests that the logic of the 1960s when children were wealth has been reversed. Nowadays, parents (mostly farmers) no longer have children just for the sake of benefiting from their aid in field work, but they also think about their education.

To a lesser extent, polygamous households were not a favourable environment to the education of children. One explanation would lie in the fact that polygamy is less and less the prerogative of well-off families, but rather that of the poor, the low income they earn does not always allow all children to go to school.

Households whose head works in the public sector are as favourable to the education of children as those whose head is inactive. This last result seems paradoxical insofar as it is necessary to spend money to send a child to school. These households led by inactive heads may receive transfers from "other parents" to cover the children's school education expenses. The households of the inactive would therefore use the income from the transfers received not only for current consumption, but also for the education of children.

In short, econometric analyses show that the probability of working is high when the child is uneducated, fatherless or orphan of both parents, and the head of the family in which he lives is uneducated, works in the agricultural sector, his standard of living is low and he lives in rural areas. This research of factors globally confirms the expected effects on the choice of children's activities. One of the reasons for putting children into labour is the characteristics of the child and those of the household to which he belongs. However, household poverty is not the only key factor explaining the involvement of children in work. It seems that the cultural diversity, the socio-economic context and the traditional organization specific to some regions constitute another important set of motivations for choosing early child labour.

\section{CONCLUSION AND RECOMMENDATIONS}

Child labour is a phenomenon which marks by its nature, its extent and its complexity. In Cameroon, as in many developing countries, working children contribute to household income. In this context, promoting the 
education of children and finding an alternative source of income for the family is a prerequisite for the effective elimination of child labour. The main objectives of this study were to take stock of the situation of child labour in Cameroon, to establish the link with poverty and education and to highlight the determinants of this phenomenon.

For a total of around 6 million children aged 5-17 years, almost four in ten children are economically employed. This percentage is roughly the same for both girls and boys. However, significant disparities are observed depending on the place of residence, the region of the survey and the age of the child. It is much more in rural areas that children find themselves economically occupied. In fact, there are $51.1 \%$ of economically employed children in rural areas against $17.9 \%$ in urban areas. Thus, most of the employed children are in the primary activities of the rural world, notably agriculture, fishing, forestry and hunting (85.2\%). Most economically employed children are unpaid. In fact, around 8 out of 10 employed children perform unpaid work as family workers. Regarding age, we note that the entry of children into the labour market increases with age, regardless of gender or region of survey.

Besides economic activities, children also participate a lot in household chores. Cleaning kitchen and household utensils, washing clothes, and collecting water and wood are the main household chores children do.

In Cameroon, the legislation in force does not prohibit all forms of child labour, whether economic or noneconomic, but it does combat certain types of activity carried out by children. It is this work which is designated by the term "child labour to be abolished". Some forms of this work are considered dangerous.

Among children, 27.9\% are involved in work to abolish and 4.4\% in hazardous work. The work to be abolished and hazardous work do not seem to be linked to sex. On the other hand, the phenomenon has strong specificities depending on the place of residence and the age of the child.

The rural environment is the place where the probability for a child to be economically occupied or even to be forced into a job to be abolished is very low, while the urban environment is where a child has more possibilities of being forced to do so. dangerous work. With regard to age, the involvement of children in hazardous work increases with age while it decreases with age for jobs to be abolished.

The work to be abolished has a consequence on the school education and the health of the children, because by forcing the boy or the girl to work, the social environment pushes them to abandon their child personality, with the impulses, the interests and the specific problems to their age. This involvement often deprives them of their most absolute rights, in particular the right to school education and the right to health. The early activity of children and more particularly the work to be abolished have a negative impact on their school attendance as well as on their health. when this work is dangerous.

With the exception of the cities of Douala and Yaoundé, children who live in poor households are more inclined to work to be abolished. However, it is necessary to explore beyond poverty to explain the employment of children.

The search for explanatory factors globally confirms the expected effects on children's choice of activities. Child labour is explained by the characteristics of the child (level of education, age and survival of the parents), those of the household to which he belongs (size, presence of children under 5 years of age, the standard of living, place of residence, survey region) and those of the head of the family (level of education, religion and socio-economic group).

Thus, the overall environment of children influences their integration into socioeconomic activities to the detriment of school attendance. In addition to these factors, cultural diversity, the socio-economic context and the traditional organization specific to some regions would constitute another set of motivations for the choice of child labour.

Following the previous analyses, there is reason to believe that the issue of child labour is more global and necessarily falls within a policy of economic and social development. Moreover, given the fact that this work is first of its kind and that it does not integrate some aspects of child labour, it is necessary that specific investigations be carried out on the worst forms of child labour other than hazardous work, in particular the sexual exploitation of children. 
Funding: This study received no specific financial support.

Competing Interests: The author declares that there are no conflicts of interests regarding the publication of this paper.

\section{REFERENCES}

Adjiwanou, V. (2005). Impact of poverty on the education and work of children aged 6 to 14 in Lomé. Paper presented at the Sixth Scientific Days of the Demography Network of the University Agency of La Francophonie on: Southern Cities: Dynamics, Diversities and Demographic and Social Issues, 22-25 November 2005. Cotonou.

Anker, R. (2000). The economics of child labor: A framework for measurement. International Labor Review, 139(3), $289-317$.

Baland, J.-M., \& Robinson, J. A. (2000). Is child labor inefficient? Journal of Political Economy, 108(4), 663-679.

Bandara, A., Dehejia, R., \& Lavie-Rouse, S. (2015). The impact of income and non-income shocks on child labor: Evidence from a panel survey of Tanzania. World Development, 67(C), 218-237.

Basu, K., \& Van, P. H. (1998). The economics of child labor. American Economic Review, 88(3), 412-427.

Basu, K., \& Tzannatos, Z. (2003). The global child labor problem: What do we know and what can we do? The World Bank Economic Review, 17(2), 147-173.

Beegle, K., Dehejia, R. H., \& Gatti, R. (2006). Child labor and agricultural shocks. Journal of Development economics, 81(1), 8096.Available at: https://doi.org/10.1016/j.jdeveco.2005.05.003.

Bhalotra, S., \& Heady, C. (2003). Child farm labor: The wealth paradox. The World Bank Economic Review, 17(2), 197227.Available at: https://doi.org/10.1093/wber/lhgo 17 .

Blunch, N.-H., \& Verner, D. (2000). Revisiting the link between poverty and child labour: The Ghanaian experience. Policy Research Working Paper, $n^{\circ}$ 2488, Washington D. C., World Bank.

Boutin, D. (2012). Family farming, child labour and the wealth paradox: Evidence from Mali. Economics Bulletin, 32(4), 34713479.

Boyden, J. (1992). Children at work in Lima, Peru. Protect children at work. New York: UNICEF.

Canagarajah, S., \& Coulombe, H. (1999). Child labor and schooling in Ghana. Policy Research Working Paper, $n^{\circ} 1844$, Washington D. C., World Bank.

Canagarajah., S., \& ET Coulombe, H. (1998). Child Labor and schooling in Ghana. Washington, DC: Banque Mondiale.

De Janvry, A., Finan, F., Sadoulet, E., \& Vakis, R. (2006). Can conditional cash transfer programs serve as safety nets in keeping children at school and from working when exposed to shocks? Journal of Development economics, 79(2), 349373.Available at: https://doi.org/10.1016/j.jdeveco.2006.01.013.

Dehejia, R., \& Gatti, R. (2002). Child labor: The role of income variability and access to credit across countries. Revision of NBER Working Paper No. 9018 (June 2002).

Diallo, Y. (2001). The determinants of child labor in Côte d'Ivoire (pp. 15). Working Document, $\mathrm{n}^{\circ} 55$, Montesquieu-Bordeaux IV University. Bordeaux, Center for Development Economics.

Diallo, Y., Étienne, A., \& Mehran, F. (2013). Global trends in child labor from 2008 to 2012. Geneva: ILO.

Diallo, Y. (2008). Children's activities in Sub-Saharan Africa: Lessons from child labor surveys in West Africa. Rome: UCW.

Dumas, C., \& Lambert, S. (2008). Child labor: Which policies for which results? Paris: Éd. Rue d'Ulm-ENS.

Dumas, C. (2007). Why do parents make their children work? A test of the poverty hypothesis in rural areas of Burkina Faso. Oxford Economic Papers, 59(2), 301-329.Available at: https://doi.org/10.1093/oep/gplo31.

Dumas, C. (2013). Market imperfections and child labor. World Development, 42, 127-142.Available at: https://doi.org/10.1016/j.worlddev.2012.08.004.

Edmonds, E. V. (2005). Does child labor decline with improving economic status? Journal of Human Resources, 40(1), 7799.Available at: https://doi.org/10.3368/jhr.xl.1.77.

Edmonds, E. V. (2006). Child labor and schooling responses to anticipated income in South Africa. Journal of Development Economics, 81(2), 386-414.Available at: https://doi.org/10.1016/j.jdeveco.2005.05.001. 
Grootaert, C. (1998). Child labor in Ivory Coast. In Grootaert, C. and Patrinos A.P. Eds.), The policy of child labor: A comparative study. New York: ST. Martin Press.

Guarcello, L., Mealli, F., \& Rosati, F. C. (2010). Household vulnerability and child labor: The effect of shocks, credit rationing, and insurance. Journal of Population Economics, 23(1), 169-198.

INS. (2008). Living conditions of populations and poverty profile in Cameroon in 2007. Main Report of Ecam III, Yaoundé.

Jensen, P., \& Nielsen, H. S. (1997). Child labour or school attendance? Evidence from Zambia. Journal of Population Economics, 1O(4), 407-424.Available at: https://doi.org/10.1007/s001480050051.

Lachaud, J.-P. (2008). Child labor and poverty in Africa: A review applied to Burkina Faso. Economie Prevision, 186(5), 47-65.

Maitra, P., \& Ray, R. (2002). The joint estimation of child participation in schooling and employment: Comparative evidence from three continents. Oxford Development Studies, 30(1), 41-62.Available at: https://doi.org/10.1080/136008101200114895.

Marcoux, R. (1993). Work or school. Child activity and household characteristics in urban areas in Mali. Doctoral Thesis. Montreal, University of Montreal.

Meka'a, B. C., \& Ewondo, M. O. (2015). Child labor: Only a problem of poverty? Effect of the economic situation of households on child labor in Cameroon. Labor and Employment, 3(143), 5-19.

Nielsen, H. S. (1998). Child labor and school attendance: Two joint decisions. Working Paper, $n^{\circ}$ 98-15, Centre for Labour Market and Social Research, Aarhus (Danemark).

Poirier, J., Baya, B., \& Zoungrana, C. (1996). Child labor and division of labor within the household. Ouagadougou: UERD.

Ravallion, M., \& Wodon, Q. (2000). Does child labor displace schooling?: Evidence on behavioral responses to an enrollment subsidy. The Economic Journal, $110(462)$, C158-C175.

Ray, R. (2000). Child labor, child schooling, and their interaction with adult labor: Empirical evidence for Peru and Pakistan. The World Bank Economic Review, 14(2), 347-367.

Tsala, Dimbuene, Z., \& Senda, L. (2005). Poverty, child labor and school attendance. Comparative analysis in urban Congolese and Central African areas. Paper presented at the Communication presented at the Sixth Scientific Days of the Demography Network of the University Agency of La Francophonie on: Southern Cities: Dynamics, Diversities and Demographic and Social Issues, 22-25 November 2005. Cotonou.

Understanding Children's Work (UCW). (2012). Cameroon: Understanding child labor and youth employment. Country Report, June 2012, Rome, UCW

Views and opinions expressed in this article are the views and opinions of the author(s), Asian Journal of Economic Modelling shall not be responsible or answerable for any loss, damage or liability etc. caused in relation to/arising out of the use of the content. 